\title{
EFFECT OF PHOSPHOROUS APPLICATION ON CHICKPEA NODULES PRODUCTION AND SOME FERTILITY PROPERTIES OF CALCAREOUS SOIL OF DUHOK-KRG- IRAQ
}

\author{
Mohammed A. Hussain ${ }^{*}$, VAhIL I. H. BARWARI AND BAKhTIYAR H. MOHAMmed ${ }^{* *}$ \\ *Dept. of Field Crops, College of Agricultural Engineering Sciences, University of Duhok, \\ Kurdistan Region - Iraq. \\ *** Dept. of Soil and Water Science, College of Agricultural Engineering Sciences, \\ University of Duhok, Kurdistan Region - Iraq
}

(Received: June 1, 2021 ; Accepted for Publication: October 13, 2021)

\begin{abstract}
Afield experiment was carried out during spring season of 2020 at research station of the College of Agricultural Engineering Sciences to evaluate the effect of different phosphorus levels on chickpea nodules production, soil physical and chemical after phosphorus application. A randomized complete block design was used, with three replications, five application rates of $\mathrm{P}_{2} \mathrm{O}_{5}, 0,15,30,45,60 \mathrm{Kg} \mathrm{ha}^{-1}$. The results revealed that the phosphorus levels were have highly significantly affected on number of nodules plant ${ }^{-1}$,seed yield, plant heigh, number of main and secondary branches per plant, first pod height and number of pods plant ${ }^{-1}$,and also, results showed the maximum number of nodules per plant(43.33) yield (667.7) $\mathrm{Kg}^{-h^{-1}}{ }^{\text {,plant height }}$ $(54.33) \mathrm{cm}$, main and secondary branches (4) and 2.3 respectively, first pod height $(26.17 \mathrm{~cm})$ and maximum pods plant ${ }^{-1} 27.67$ was recorded at maximum rate of phosphorus, $\left(60 \mathrm{Kg}^{-h^{-1}}\right)$ Regarding agronomic efficiency percent, the results exhibited maximum value of this percent was recorded at $60 \mathrm{Kg} \cdot \mathrm{ha}^{-1} \mathrm{P}_{2} \mathrm{O}_{5}$, the results indicated application of $60 \mathrm{Kg}^{-h^{-1}}$ gave the highest values for all studied traits and recorded highest value of coefficient determination $\left(\mathbf{R}^{2}\right)$ $0.95,0.94,0.91$ and 0.99 , for plant height, secondary branches per plant, pod height and number of pod plant $^{-1}$ respectively. The results exhibited highly significant and positive correlation for seed yield $0.92,0.90,0.87$ and 0.84 with number of pods plant ${ }^{-1}$, plant height, number of main and secondary branches plant ${ }^{-1}$ respectively. Application of phosphorus the soil increases some physical and chemical properties of soil such as $\mathrm{pH}$, EC, available of phosphorus, organic matter and cation exchange capacity.
\end{abstract}

KEY WORD: chickpea, production, phosphorus, local variety.

\section{INTRODUCTION}

$\mathbf{P}$ hosphorus is considered an important nutrient for formation and translocation of carbohydrate, fatty acid, and other essential inter compound. An application of phosphorus has been found to improve the roots system of plant. Phosphorus caused increase in the lateral and fibrous roots, which results in more nodule bacteria increase in the rate of nitrogen fixation in leguminous crops. (Siphiwe et al.,2017)

Chick pea (Cicer arietinum L) is an important pulse crop, it recognized as legume with source of protein, nutrients, and carbohydrates (laranjo ,2014). It is adaptable to wide climate variation, has low production cost and promotes biological fixation of atmospheric nitrogen. (Nascimento, 2016 and Bala, 2017).

Khan et al.,2010 indicated the production is limited by lack of plant nutrient available in the soil because majority of farmers hardly use of fertilizer for legume cultivation, However, there is a possibility to enhance the productivity through optimum fertilization and management, as there is a wide gap between the average yield production and yield potential of crop. Plant nutrition, suitable cultivars and correct fertilizer has 
significant effect on yield and yield components.

Phosphorus effect on the number of nodules, number of pods, weight of pods, green pods yield and protein content(percent) were markedly increased with increasing phosphorus levels up to 60 Kg.ha ${ }^{-1}$ over control (Dotaniya et al., 2014).

Phosphorus fertilization is among the main practices of crop management, yet, it is considering complex in tropical soils because of the high capacity of phosphorus for covalent adsorption to soil (Gazola et al., 2013) and because of low natural availability of $P$ to plant. In chickpea balanced phosphorus nutrition in fundamental for establishing symbiosis with nitrogen fixing rhizobacteria and it stimulates nodulation, in development of roots, plant growth and seed yield and quality (Balai et al., 2017).Also phosphorus variability in optimum quantities is needed for early growth stage, development of the reproductive parts, root growth, reduced disease incidence and early maturity compare to vegetative growth. Phosphorus availability in considerable quantities is critically need for seed yield. (Gidagoe et al., 2012)

The aim of this study was to evaluate chickpea yield and soil chemical and physical attributes under different application rates of phosphorus.

\section{MATERIALS AND METHODS}

The influence of phosphorus levels on yield and some growth parameters were estimated in an experiment carried out at the field of College Agricultural
Engineering Sciences- Dohuk University Iraqi Kurdistan Region. The experiment units were laid out in randomize complete block design (RCBD) with three replicates. The experiment units consist four rows with four-meter length and the distance between rows $0.30 \mathrm{~m}$ (with plot size $3.6 \mathrm{~m}^{2}$ ).

Local variety of chickpea and five triple super phosphate $\mathrm{P}_{2} \mathrm{O}_{5}$ doses $\left(0,15,30,45\right.$ and60 Kg.ha $\left.{ }^{-1}\right)$ were applied before planting date with planting lines. Experimental managed in accordance with the recommended cultural and other field management practices such as hand weeding, nitrogen application. The data were recorded randomly on five plants and these plants at the end of flowering and it was washed with water and then the counting process started for the number of nodule per plant seed yield $\mathrm{Kg}_{\mathrm{g}} \mathrm{ha}^{-1}$,plant height $\mathrm{cm}$, number of main and secondary branches per plant, first pod height and number of pod plant. The agronomic efficiency was calculated by using the following formula

$A E=\frac{\text { YFT-YCT }}{\text { ARFT }} \quad$ (MC Donald et al., 2001)

Where,

$\mathrm{AE}=$ Agronomic efficiency in $\mathrm{Kg}$ of seeds per

Kg nutrient applied

YFT $=$ Yield in treatment fertilized with $\mathrm{P}, \mathrm{Kg}$. $\mathrm{ha}^{-1}$

YCT $=$ Yield in control treatment $\mathrm{Kg} \cdot \mathrm{ha}^{-1}$

$\mathrm{ARFR}=$ Application rate in treatment fertilizer with P, Kg. ha ${ }^{-1}$

The monthly climatology information was obtained from the station of College Agricultural Engineering Sciences, Table 1. 
Table:(1): The climatic of the experimental field location during growing season 2020- 2021, (rainfall and air temperatures).

\begin{tabular}{|c|c|c|c|c|}
\hline \multirow[t]{2}{*}{ Years } & \multirow[t]{2}{*}{ Months } & \multirow[t]{2}{*}{ Rainfall mm } & \multicolumn{2}{|c|}{ Temperature $\mathrm{C}^{\circ}$} \\
\hline & & & Max. & Min. \\
\hline 2019 & Oct. & 3 & 30.8 & 18.2 \\
\hline 2019 & Nov. & 30 & 22.1 & 9.3 \\
\hline 2019 & Dec. & 107 & 14.6 & 6.9 \\
\hline 2020 & Jan. & 89.5 & 10.6 & 4.1 \\
\hline 2020 & Feb. & 76 & 11.7 & 4.3 \\
\hline 2020 & Mar. & 310 & 18.6 & 9.8 \\
\hline 2020 & Apr. & 55 & 19.8 & 10.7 \\
\hline 2020 & May & 16.5 & 21.2 & 11.6 \\
\hline
\end{tabular}

The important physico-chemical properties of these soils $(\mathrm{pH}$, EC. organic matter, particle size distribution, CEC, Available phosphorus, etc.) were determined by following methods described by Jackson (1973). The data were subjected to analyzed of variance with (mantab analysis program, 2017) and using Duncan's Multiple Range Test (MRT) to determine the superiority of treatment means.

\section{RESULTS AND DISCUSSION}

The analysis of variance for the studied traits of chickpea under varying levels of phosphorus presented in Table 2. The results revealed that the phosphorus levels have significant effected on number of nodules plant $^{-1}$, seed yield, plant height, number of main and secondary branches, first pod height and number of pods plant ${ }^{-1}$. These results are similar to finding of Lopes, 2016 and Oliveira et al., 2017. Who reported that the phosphorus application enhances growth as well as yield contributing growth parameters of the chickpea.

Table (2): Analysis of variance for studied traits chickpea under different levels of phosphorus.

\begin{tabular}{ccccccccc}
\hline S.O.V & d.f & No. of nodule & $\begin{array}{c}\text { yield Plants } \\
\text { Kg }\end{array}$ & $\begin{array}{c}\text { Plant height } \\
\mathbf{c m}\end{array}$ & $\begin{array}{c}\text { No. of main } \\
\text { branch } \\
\text { Plant }\end{array}$ & $\begin{array}{c}\text { No. of } \\
\text { secondary } \\
\text { branch } \\
\text { Plant }^{-1}\end{array}$ & $\begin{array}{c}\text { Pod height cm } \\
\text { No. of pod } \\
\text { Plant }\end{array}$ \\
\hline Replication & 2 & 114.87 & 286 & 95.76 & 0.0667 & 1.8000 & 27.950 \\
\hline Treatments & 5 & $236.90^{* *}$ & $75742^{* *}$ & $140.13^{*}$ & $1.6000^{* *}$ & $7.9333^{* *}$ & $8.942^{* *}$ \\
\hline Error & 10 & 32.45 & 230 & 92.94 & 0.1500 & 0.6333 & 2.992 \\
\hline Total & 17 & & & & & & & \\
\hline
\end{tabular}

${ }^{*}$ significant at probability $0.05,{ }^{* *}$ significant at probability 0.01 .

Effect of different phosphorus levels on studied traits were presented in Table, 3. The results showed that, the maximum number of nodules plant $^{-1}$ was (43.33) recorded when fertilizer with $\left(60 \mathrm{Kg} \mathrm{P}_{2} \mathrm{O}_{5}\right.$ $\mathrm{ha}^{-1}$ ) and the minimum number of nodules per plant 20.67 recorded at fertilizer treatment $\left.15 \mathrm{Kg} \quad \mathrm{P}_{2} \mathrm{O}_{5} \mathrm{ha}^{-1}\right)$. The result in 
relation relying on to the grain yield $\mathrm{Kg}$. ha 1 of chickpea as under the effect of various phosphorus levels, grain yield value was (667.7 Kg.ha $\left.{ }^{-1}\right)$ was obtained by $(60 \mathrm{Kg}$ $\mathrm{P}_{2} \mathrm{O}_{5} \mathrm{ha}^{-1}$ ) application while, the lowest value $315.2 \mathrm{Kg}$. $\mathrm{ha}^{-1}$ was recorded in control with no phosphorus application. Depending on the plant height the maximum plant height $(54.33 \mathrm{~cm})$ was observed at fertilizer treatment $\left(60 \mathrm{Kg} \mathrm{P}_{2} \mathrm{O}_{5}\right.$ $\mathrm{ha}^{-1}$ ) whilst, the minimum plant height $(38.03 \mathrm{~cm})$ was noted in control treatment.

The number of main and secondary branches per plant increased with increasing phosphorus rate. Maximum numbers branches (4.00) and 8.33 recorded at fertilizer treatment $60 \quad \mathrm{Kg} \quad \mathrm{P}_{2} \mathrm{O}_{5} \quad \mathrm{ha}^{-1}$, minimum number of branches plant (2) and (4) respectively were obtained by zero phosphorus application. Regarding to first pod height the highest value (26.17) were recorded at $60 \mathrm{Kg} \mathrm{P}_{2} \mathrm{O}_{5} \mathrm{ha}^{-1}$ while, lower value (22.33) was recorded at control treatment. The data in Table (2) showed that the number of pod per plant increasing when plant received to $60 \mathrm{Kg} \mathrm{P}_{2} \mathrm{O}_{5} \mathrm{ha}^{-1}$, pods per plant (27.67) were recorded at the maximum rate of phosphorus and the minimum value (11) was obtained in zero phosphorus application on the basis of the results in the Table (3), thus can it concluded that the application of

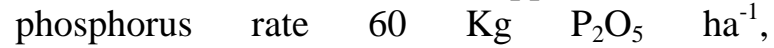
significantly improved agronomic traits, plant height, number of main and secondary branches, number of nodules per plant and number of pods plant $^{-1}, \quad 100$ seed weight and grain yield because phosphorus helped to increase the size of the root system, which led to an increase the absorption the nutrients from soil. Observations confirmations these founding by Bala. 2017, Seid et al., 2015 and Laranjo et al., 2014.

Table (3): Mean of the studied traits of the chickpea under different phosphorus levels.

\begin{tabular}{cccccccc}
\hline Treatments & $\begin{array}{c}\text { No. of } \\
\text { Nodules } \\
\text { plant }\end{array}$ & $\begin{array}{c}\text { Seed yield } \\
\text { kg.ha }{ }^{-1}\end{array}$ & $\begin{array}{c}\text { Plant height } \\
\mathbf{C m}\end{array}$ & $\begin{array}{c}\text { No. of main } \\
\text { branches } \\
\text { Plant }^{-1}\end{array}$ & $\begin{array}{c}\text { No. of } \\
\text { secondary } \\
\text { branches } \\
\text { Plant }^{-1}\end{array}$ & $\begin{array}{c}\text { First pod } \\
\text { height } \\
\mathbf{c m}^{2}\end{array}$ & $\begin{array}{c}\text { No. of } \\
\text { pods. } \\
\text { plant }\end{array}$ \\
\hline control & $25.670 \mathrm{~b}$ & $315.200 \mathrm{~d}$ & $38.030 \mathrm{a}$ & $2.000 \mathrm{~b}$ & $4.667 \mathrm{c}$ & $22.330 \mathrm{a}$ & $11.000 \mathrm{~d}$ \\
\hline 15 & $20.670 \mathrm{ab}$ & $346.500 \mathrm{~d}$ & $51.330 \mathrm{a}$ & $2.667 \mathrm{~b}$ & $4.667 \mathrm{c}$ & $23.000 \mathrm{a}$ & $14.670 \mathrm{~cd}$ \\
\hline 30 & $23.330 \mathrm{~b}$ & $394.200 \mathrm{c}$ & $52.670 \mathrm{a}$ & $2.667 \mathrm{~b}$ & $6.000 \mathrm{bc}$ & $24.500 \mathrm{a}$ & $18.670 \mathrm{bc}$ \\
\hline 45 & $28.330 \mathrm{~b}$ & $600.700 \mathrm{~b}$ & $54.000 \mathrm{a}$ & $3.000 \mathrm{ab}$ & $7.333 \mathrm{ab}$ & $26.000 \mathrm{a}$ & $23.000 \mathrm{ab}$ \\
\hline 60 & $43.330 \mathrm{a}$ & $667.700 \mathrm{a}$ & $54.330 \mathrm{a}$ & $4.000 \mathrm{a}$ & $8.333 \mathrm{a}$ & $26.170 \mathrm{a}$ & $27.670 \mathrm{a}$ \\
\hline p. value & 0.009 & 0.000 & 0.278 & 0.003 & 0.002 & 0.088 & 0.000 \\
\hline
\end{tabular}

Means that do not share a letter are significantly different at $p$ value $<0.05$.

The data in Table (4) indicating the agronomic efficiency percent under different levels of phosphorus application. The results exhibited that the maximum value was recorded at $60 \mathrm{Kg} \mathrm{P}_{2} \mathrm{O}_{5} \mathrm{ha}^{-1}$ and was $1.469 \%$, while the lower value $5.22 \%$ was obtained at $15 \quad \mathrm{Kg} \quad \mathrm{P}_{2} \mathrm{O}_{5} \quad \mathrm{ha}^{-1}$,fertilizer level so, it necessary to use an adequate amount of plant nutrients at balanced rates for improving plant growth, yield and yield components. Similar results were obtained by Prajapati et al., 2017. 
Table (4): Agronomic efficiency under different levels of phosphorus.

\begin{tabular}{ccccc}
\hline treatment & YFT & YCT & ARFT & AE \\
\hline 15 & 346.5 & 315.2 & 60 & 0.522 \\
\hline 30 & 394.2 & 315.2 & 120 & 0.658 \\
\hline 45 & 600.7 & 315.2 & 180 & 1.586 \\
\hline 60 & 667.7 & 315.2 & 240 & 1.469 \\
\hline
\end{tabular}

Where,

YFT $=$ Yield in treatment fertilized with $\mathrm{P}, \mathrm{Kg} . \mathrm{ha}^{-1}$

YCT $=$ Yield in control treatment $\mathrm{Kg} . \mathrm{ha}^{-1}$

$\mathrm{ARFR}=$ Application rate in treatment fertilizer with $\mathrm{P}, \mathrm{Kg} . \mathrm{ha}^{-1}$

$\mathrm{AE}=$ Agronomic efficiency in $\mathrm{Kg}$ of seeds per $\mathrm{Kg}$ nutrient applied

Fig.1(A to G) the application of $60 \mathrm{Kg}$ $\mathrm{P}_{2} \mathrm{O}_{5}$ ha $^{-1}$ gave the highest value of all studied traits and the same figure showed that the plant height, secondary branches, also the figure show, first pod height and number of pod plant ${ }^{-1}$, was most components of chickpea attributes the seed yield after phosphorus application and recorded the correlate between yield and some of the traits by adding the phosphorus element were high and here the effective role of phosphorus in different traits appears at high doses to get the best growth and productivity. the highest value of coefficient determination (R) 0.95, 0.94, 0.94, and 0.99 respectively.

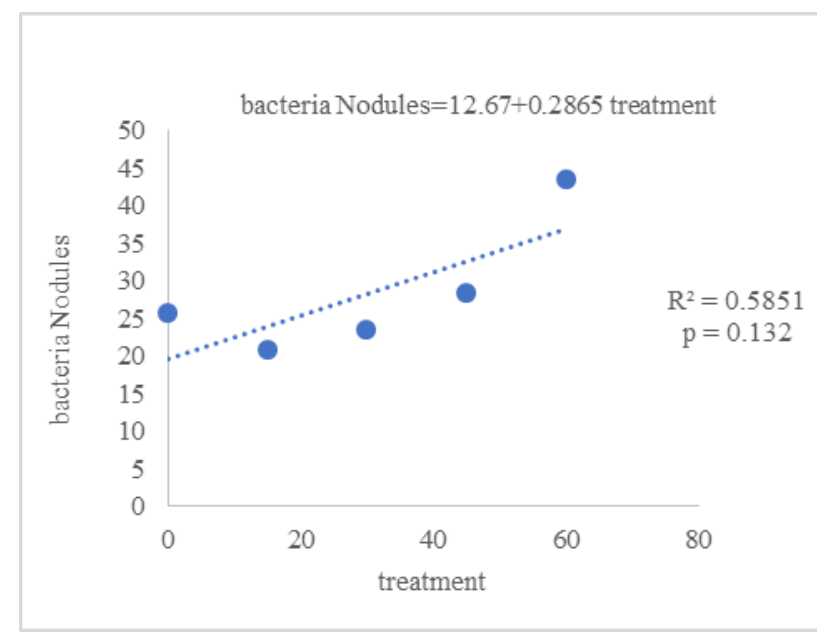

(A)

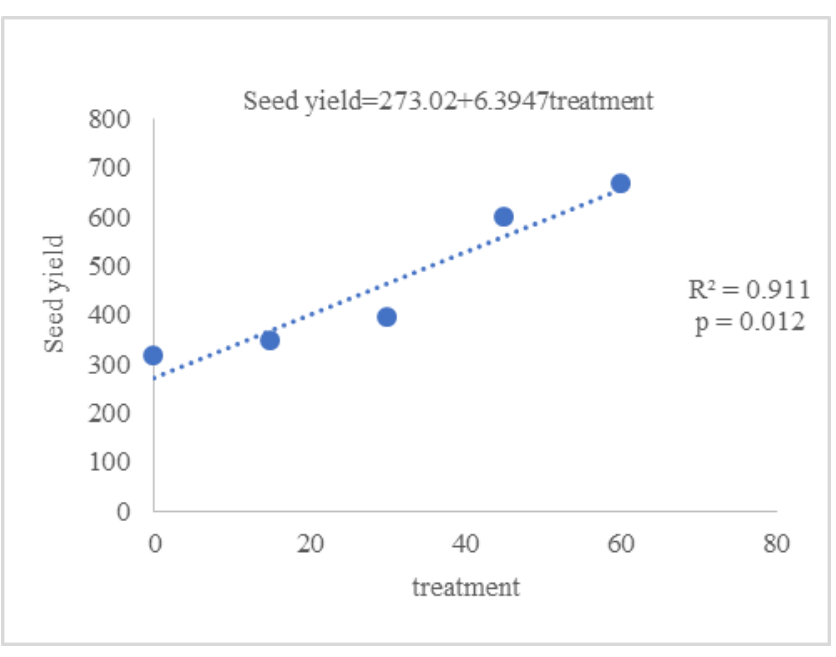

(B) 


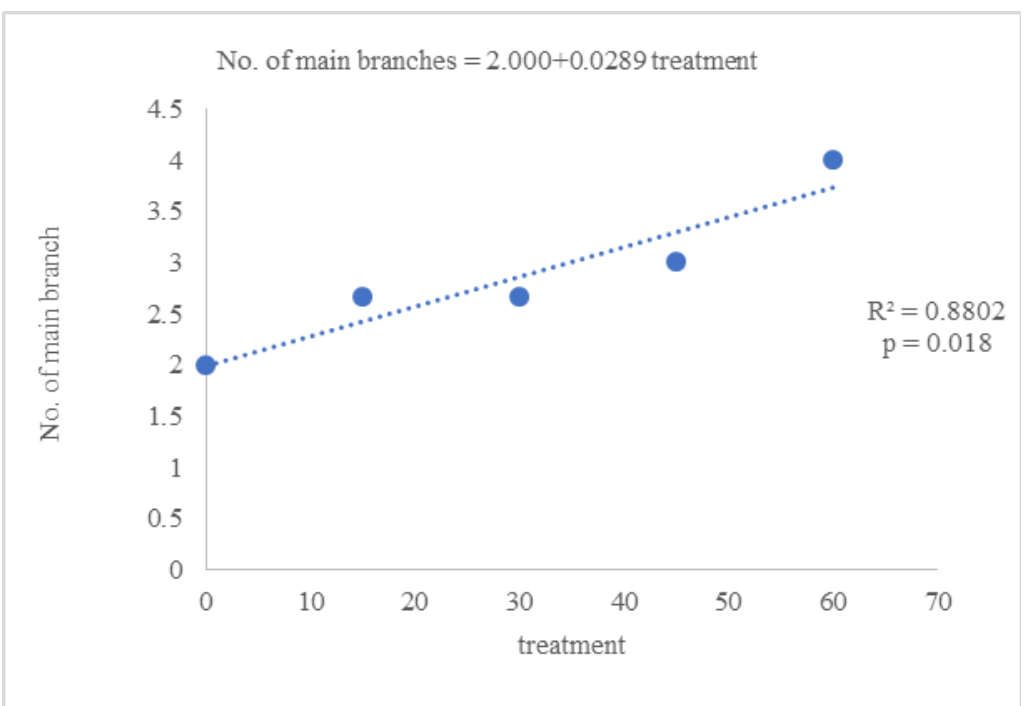

(C)

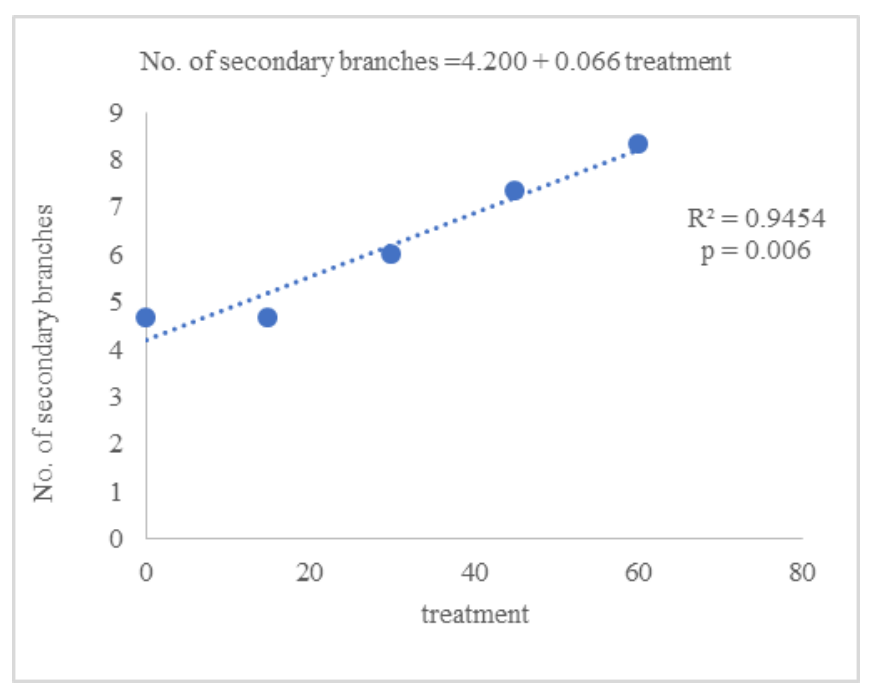

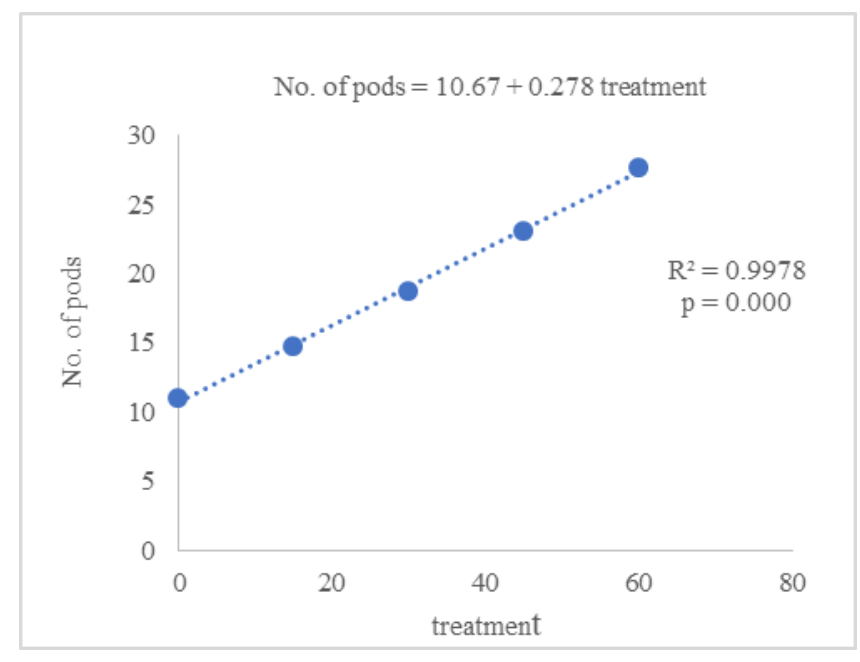

(D)

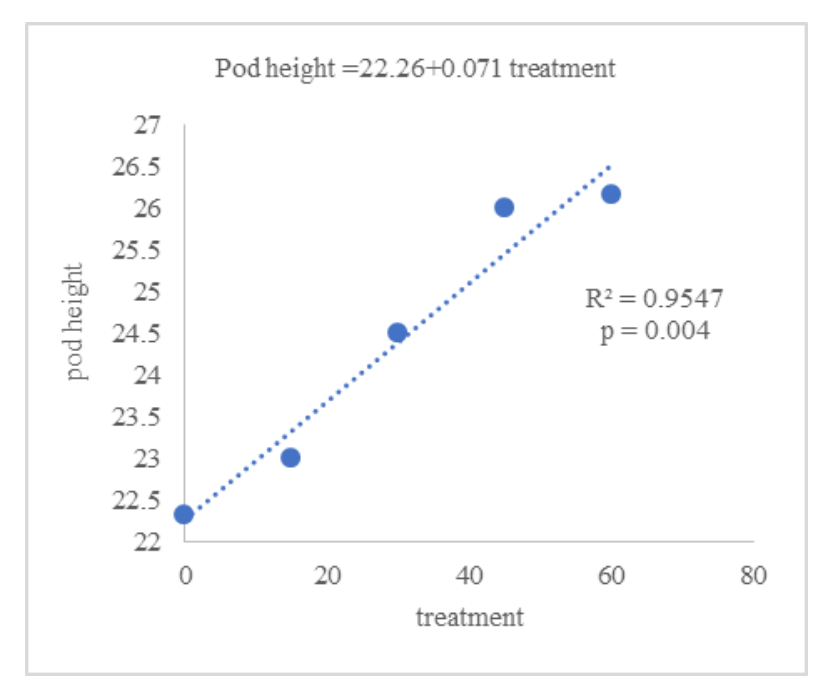

(F)

(E)

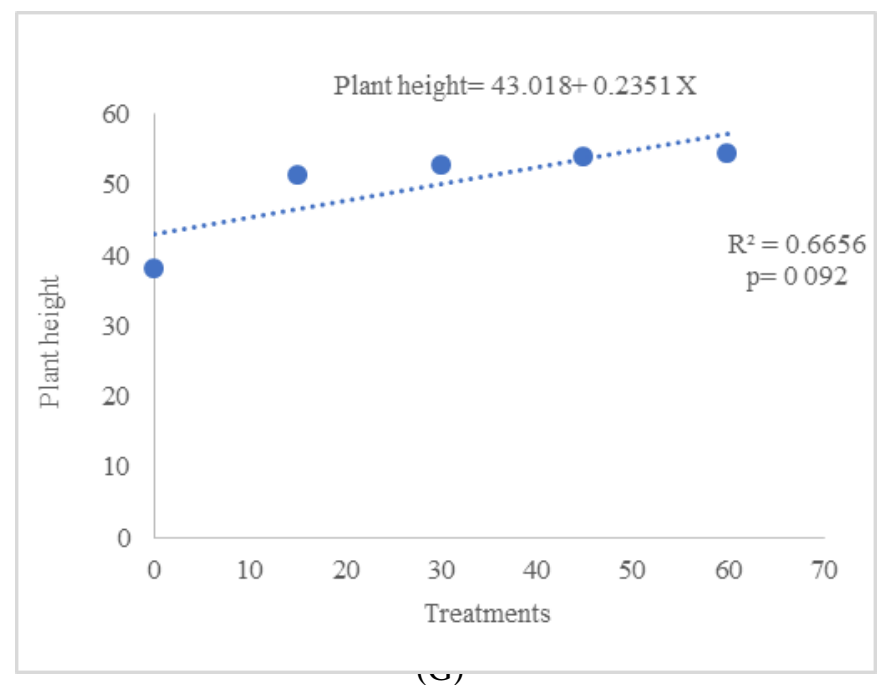


From the data in Tables 5, the results indicated highly a significant and positive correlation among studied parameters of chickpea. For seed yield were 0.922, 0.90, 0.87 , and 0.84 with number of pods plant ${ }^{-1}$, plant height, number of main and secondary branches plant ${ }^{-1}$ respectively. For the number of nodules plant ${ }^{-1}$ also observed highly significant and positive correlation with seed yield and the value was 0.84, while the secondary branches plant were positively correlated with number of nodules plant (0.79) and seed yield (0.89) and (0.79) with plant height. Similar results were also confirmed by many researches Jakhar, 2014, and Amare et al., 2020.

Table (5): simple correlation coefficient between yield and some growth parameters in chickpea.

\begin{tabular}{|c|c|c|c|c|c|c|}
\hline Parameters & $\begin{array}{c}\text { No. of } \\
\text { Nodules }\end{array}$ & $\begin{array}{l}\text { Seed yield } \\
\mathrm{kg} \cdot \mathrm{ha}^{-1}\end{array}$ & $\begin{array}{l}\text { Plant } \\
\text { height } \\
\mathrm{cm}\end{array}$ & $\begin{array}{l}\text { No. of main } \\
\text { branches }\end{array}$ & $\begin{array}{c}\text { No. of } \\
\text { secondary } \\
\text { branches }\end{array}$ & Pod height \\
\hline Seed yield kg. ha-1 & $0.879^{\star *}$ & & & & & \\
\hline Plant height $\mathrm{cm}$ & $0.784^{\star \star}$ & $0.923^{\star \star}$ & & & & \\
\hline No. of main branches & $0.829^{\star *}$ & $0.806^{\star \star}$ & $0.757^{\star \star}$ & & & \\
\hline No. of secondary branches & $0.793^{\star \star}$ & $0.890^{\star \star}$ & $0.793^{\star *}$ & $0.702^{\star *}$ & & \\
\hline Pod height & $0.571^{*}$ & $0.562^{*}$ & $0.592^{*}$ & 0.462 & $0.568^{*}$ & \\
\hline No. of pods & $0.849^{* *}$ & $0.922^{\star \star}$ & $0.909^{* *}$ & $0.871^{\star *}$ & $0.842^{\star *}$ & 0.447 \\
\hline
\end{tabular}

Thus, application to soil in this study increase some physical and chemical properties of soil in Table 6 . the results in the same table exhibited that reduction of $\mathrm{pH}$ from 7.9 to 7.61 and $\mathrm{EC}$ from 0.557 to 0.520 while the increase of phosphorus application rates change in physical and chemical attributes and increased in a variable phosphorus, organic matter, cation exchange capacity, and recorded values $4.08,18.8,32.4$ respectively. this relation was considered positive for plant development. This is in line with finding of Rodinel et al., 2018 and Dotaniya et al., 2014. 
Table (6): The chemical and physical properties of soil experimental site.

\begin{tabular}{|c|c|c|c|}
\hline Parameters & Units & $\begin{array}{c}\text { (Depth 0-30) } \\
\text { Before planting }\end{array}$ & $\begin{array}{c}\text { (Depth 0-30) } \\
\text { After planting }\end{array}$ \\
\hline $\mathrm{Ph}$ & $1: 2$ & 7.96 & 7.61 \\
\hline EC & ds. $m^{-1}$ & 0.557 & 0.520 \\
\hline $\mathrm{Ca}^{2+}$ & $\mathrm{mmol}_{\mathrm{C}} \cdot \mathrm{L}^{-1}$ & 2.50 & 2.42 \\
\hline $\mathrm{Mg}^{2+}$ & $\mathrm{mmol}_{\mathrm{C}} \cdot \mathrm{L}^{-1}$ & 2.30 & 2.08 \\
\hline $\mathrm{Na}^{+}$ & $\mathrm{mmol}_{\mathrm{C}} \cdot \mathrm{L}^{-1}$ & 0.34 & 0.42 \\
\hline $\mathrm{K}^{+}$ & $\mathrm{mmolc}_{\mathrm{C}} \mathrm{L}^{-1}$ & 0.19 & 0.20 \\
\hline $\mathrm{HCO}_{3}{ }^{-}$ & $\mathrm{mmol}_{\mathrm{C}} \mathrm{L}^{-1}$ & 3.80 & 3.68 \\
\hline $\mathrm{CO}_{3}{ }^{=}$ & $\mathrm{mmolc}^{-\mathrm{L}^{-1}}$ & Appear & Appear \\
\hline $\mathrm{Cl}^{-}$ & $\mathrm{mmolc}^{-\mathrm{L}^{-1}}$ & 0.74 & 0.72 \\
\hline $\mathrm{SO}_{4}{ }^{=}$ & $\mathrm{mmolc}_{\mathrm{L}} \mathrm{L}^{-1}$ & 0.70 & 0.66 \\
\hline Available phosphorus $\mathrm{P}$ & ${\mathrm{Mg} \cdot \mathrm{kg}^{-1}}^{-1}$ & 3.89 & 4.08 \\
\hline Organic matter & g. $\mathrm{kg}^{-1}$ & 17.5 & 18.8 \\
\hline Cation exchange capacity & $\mathrm{Cmol}^{\mathrm{kg}}{ }^{-1}$ & $29 . .8$ & 32.4 \\
\hline Total calcium carbonate & g. $\mathrm{kg}^{-1}$ & 212 & 218 \\
\hline Sand & $\mathrm{g} \cdot \mathrm{kg}^{-1}$ & $\begin{array}{l}\text { Soil texture } \\
\text { silty clay }\end{array}$ & 78 \\
\hline Silt & $\mathrm{g} \cdot \mathrm{kg}^{-1}$ & 432 & 430 \\
\hline Clay & $\mathrm{g} \cdot \mathrm{kg}^{-1}$ & 484 & 492 \\
\hline Bulk density & $\mathrm{g} . \mathrm{cm}^{-3}$ & 1.29 & 1.23 \\
\hline
\end{tabular}

Phosphorous Applications

\begin{tabular}{cc}
\hline Treatment & $\begin{array}{c}\text { Available } \\
\text { phosphorous } \\
\text { (mg.kg) }\end{array}$ \\
\hline Control 0 & 3.89 \\
\hline 15 & 4.88 \\
\hline 30 & 6.9 \\
\hline 45 & 7.7 \\
\hline 60 & 7.92 \\
\hline
\end{tabular}

\section{REFERENCES}

Amare. T, Asnake. $\mathrm{F}$ and Bantayhu. M. (2020). Genetic variability and association analysis of Desi-type chickpea advanced lines under potential environmental in north Gondar Ethiopia. Congent food and Agriculture 6(1): 1-36.

Bala. L. K. (2017). Effect of phosphorus and zinc on growth, yield and economics of chick pea. Inter. of current microbiology and applied sciences. 6 (3): 1174-1181.

Balai.K, sharma.Y, Jajoria.M, Deewan.P and R. Verma. (2017). Effect of phosphorus and zinc on growth, yield and economics of chickpea. International Journal of current microbiology and applied sciences. 6 (3) 1174-1181.

Dotaniya. Ml,pingoliya. K. K, M. Lata, R, Vema, K. L. Decwan, P. Dolanyia. 
(2014). Role of phosphorus in chick pea production. African. J. of Agric. Research. 9(51):3736- 3743.

Gazola. P.N. moria and A. condido (2013). Efeito residual do aplicacao de fosfato monoamonio revestido por differents polimeros nacultura de milho . Revista Ceres. 60 (6) 876884.

Gidago G, S. Beyene and W. Worku. (2012). The response of haricot bean (Phaseolus vulgaris L.) to phosphorus application on ultisols at Areka, Southern Ethiopia. J. Biol. Agric. Healthc. 1(3):38-49.

Jackson, M.L. (1973). Soil Chemical Analysis. Prentice Hall of India Pvt. Ltd, New Delhi.

Jakhar, D.A, N. S. (2014). Genetic diversity studies in chickpea. Bangladesh. J. of Botany 45(3) :459-464.

Khan, H.R. (2010). Response of chickpea (Cicer arietinum L.) to zinc supply and water deficits. Ph.D. Decertation. Span. J. Agric. Res. 8(3): 797-807.

Laranjo. M, A. Alexander and Solivira. (2014). Legume growth-promoting rhizobia: an overview on the Meso rhizobium genus. Microbiological research. 169(1): 2-17.

Lopes. J. F. (2016). Productive ecomposicao meineral do feilao em respota as aduabaco es mibedinio enianel Revista Cereas 63 (3): 419-426.

McDonald, G.K., Graham, R.D., Lloyd, J., Lewis, J., Lonergan, P., KhabazSaberi, H. (2001). Breeding for improved zinc and manganese efficiency in wheat and barley. Proceeding of the 10th Australian Agronomy Conference. Department of Plant Science, Waite Institute, Glen Osmond, SA, Hobart.

Nascimentos. W. M. And A.Bala (2016). Hortalicas Leguminosa. Brasilia Empresa Brasileira de pesquisa Agro pecuaria $5,(2): 232-237$.

Oliveira. C. (2017). Producao de sementes de soja enriqueuecidas com phosphorus. Revista C eres, 64 (3):282-290.

Prajapati. B. J, Nitin. G. A. Gamit and H.J. chhaganiya. (2017). Effect of integrated phosphorus management on growth, yield attributes and yield of chickpea. Forming and management 2(1):36-40.

Rodinel. F. P., N. Maria, A. candido and M. Rodrigues. (2018). Chick pea production and soil chemical attributes after phosphorus and molybdenum fertilization. Ciancia Agrotechologia.42(5) 474-483.

Seid. H., Yirga. F and F. Tibebu. (2015). Effect of phosphorus fertilizer on yield and yield components of chick pea. International J. of Agri. Extension and Rual Development studies. (1) (1) : 29-35.

Siphiwe. G.Z, Jude. J. O and B.O. John. (2017). Growth, yield and water efficiency of chick pea (Cicer arietinum): response to biochar and phosphorus fertilizer application. Archives of Agronomy and soil science. $\quad 10 \quad$ (1):1-15. 
كارتيّكرنا زيدهرنا فوسفورى ل سهر بهرههم ئينانا كريّكيّن نوكا و هندهك تايبهت مهندييت فيزيايى و

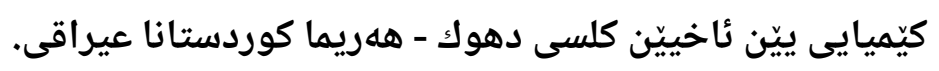

يوخته

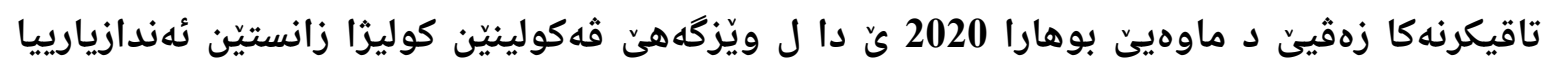

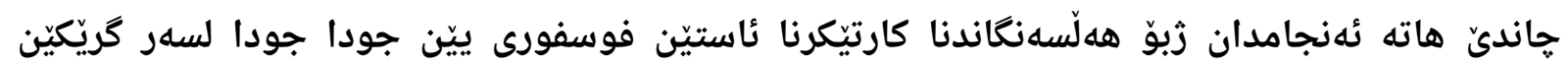
بهرههمى و تايبهتمهندى ييّن فيزيايى و كيّميايى ييّن ئاخى يشتى زيّدهكرنا فوسفورى. ديزاينا كهرتيّن

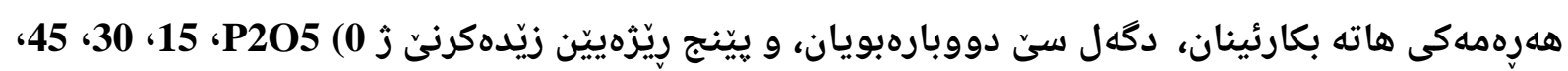

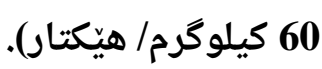

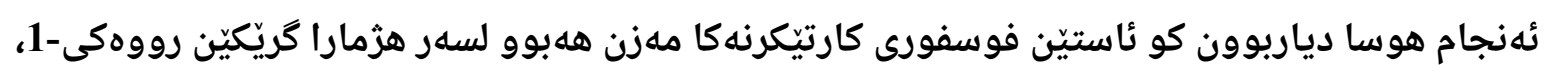

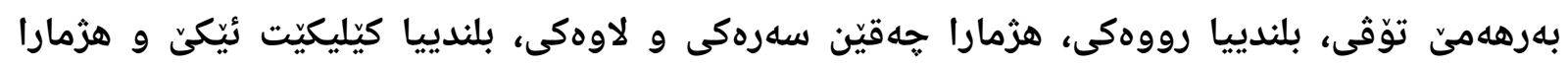

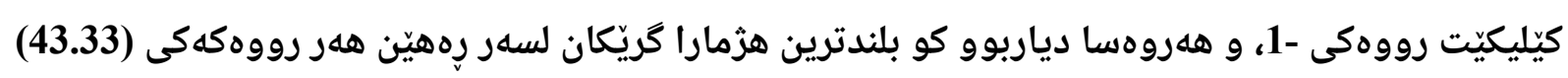

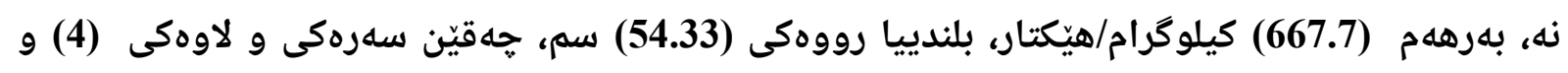

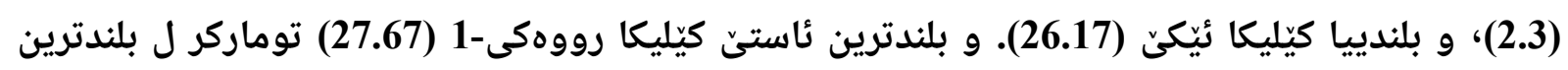

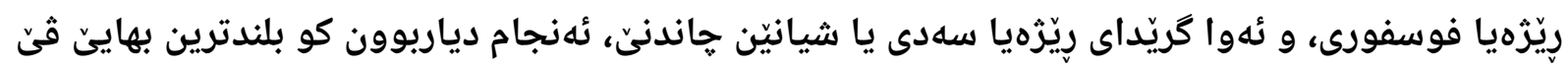

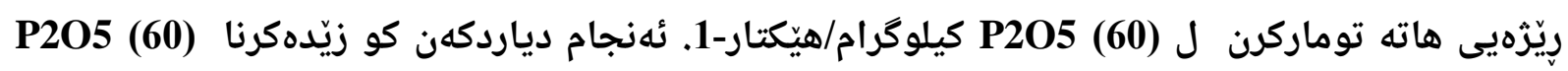
كيلوگرام/هيّكتار-1 دا بلندترين بهاى بوّ ههمى تايبهتمهندى ييّن خواستى

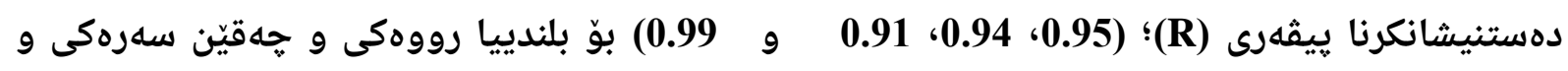

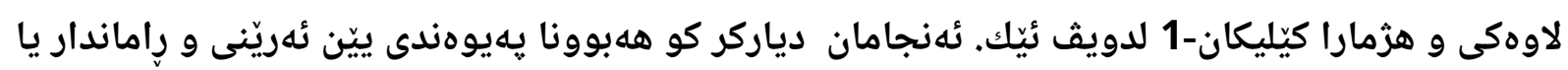

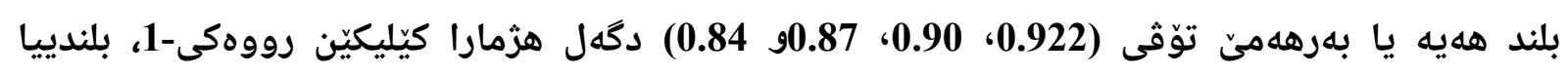

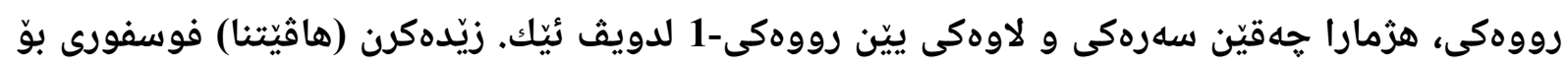

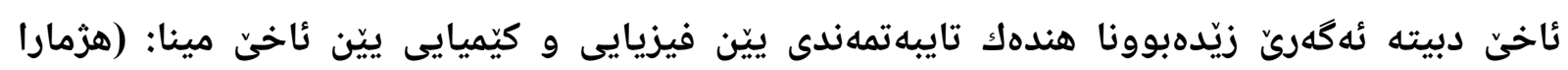

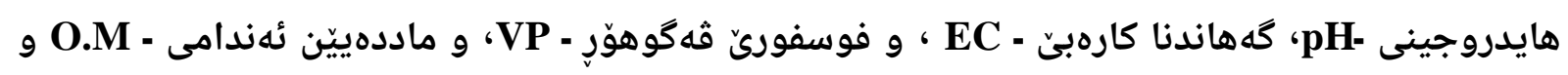

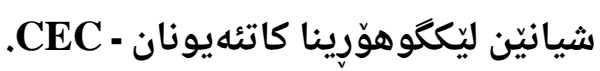
شوكه يهيف: نوّك، بهرههم، فوسفور،جورِى نافخويى 
تاثير الفسفور المضاف على انتاج العقد البكتيرية للحمص وبعض الخصائص الخصوبية للتربة الجبسية . دهوك- اقليم كوردستان العراق

الخلاصة

طبقــت تجربــة حقليـة خـلال الموسـم الربيعـي لعـام 2020 فــي حقـل كليـة علـوم الهندسـة الزراعيـة

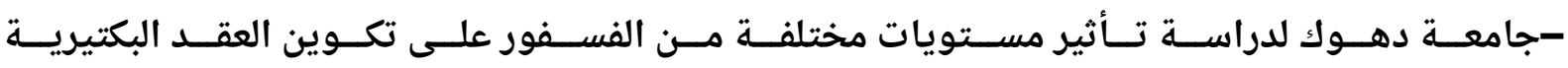
وخصـائص التربـة الفيزياويــة والكيمياويــة باسـتخدام تصـميم القطاعـات العشـــائية الكاملـة وبـــلاث مكررات.

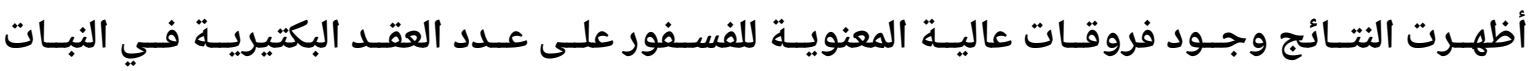

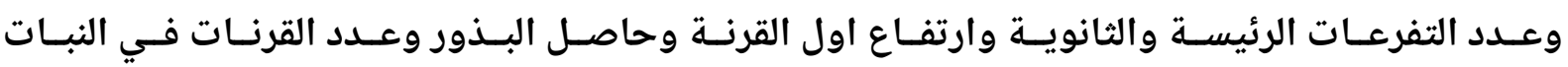

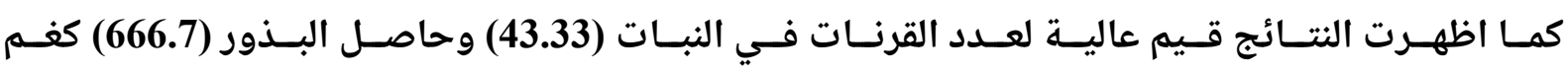

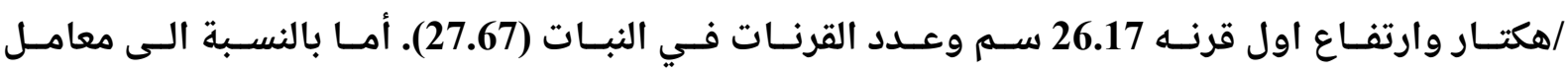

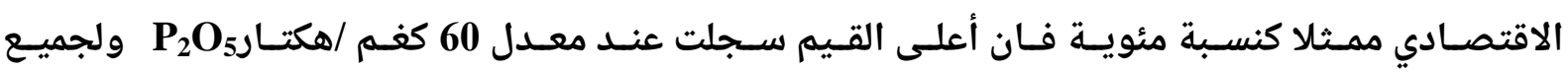

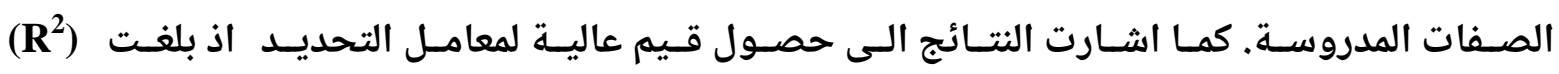

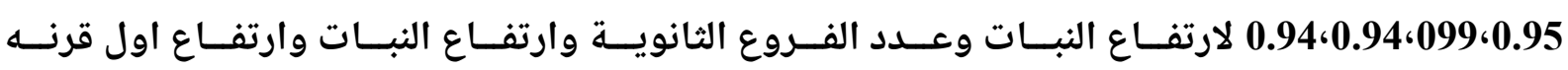

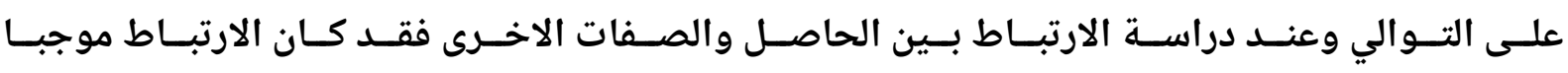

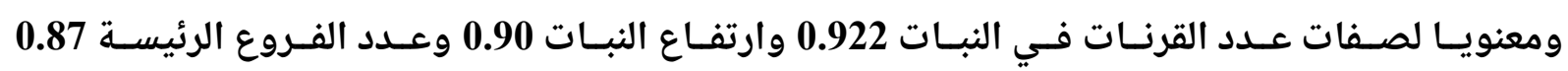

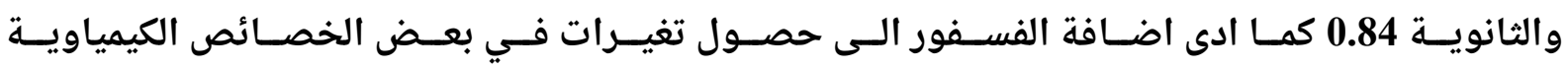

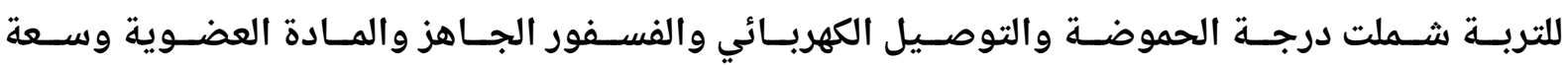
التبادل الكاتيوني . كلمات مفتاحية: حمص، انتاج، فسفور، صنف محلي 